\title{
A TEORIA LIBERAL DA COMBINAÇÃO DE PODERES
}

\author{
Camila Oliveira do Valle*
}

Resumo: A pesquisa analisa as teorias dos poderes desenvolvidas por Locke, por Montesquieu e por Hamilton, Madison e Jay. Os Federalistas consolidam na Constituição Estadunidense os "Três Poderes" apresentados e desenvolvidos por Montesquieu e por Locke. Questionando a concepção de "separação", a pesquisa conclui que os autores elaboram uma teoria da combinação dos poderes, os quais interagem entre si. Essa base teórica liberal fundamenta a organização de Poderes adotada pelo Brasil com a Constituição da República Federativa, em 1988, que consolidou o Poder Legislativo, o Executivo e o Judiciário, apresentando suas atribuições e funções e prevendo a ingerência de um poder no outro.

Palavras-chave: Poderes; Brasil; Liberalismo.

\section{THE LIBERAL THEORY OF THE COMBINATION OF POWERS}

\begin{abstract}
The research analyzes the theories of the powers developed by Locke, Montesquieu and Hamilton, Madison and Jay. The Federalists consolidated in the US Constitution the "Three Powers" presented and developed by Montesquieu and by Locke. Questioning the concept of "separation", it concludes that the authors elaborate a theory of the combination of powers, which interact. This theoretical liberal basis based the organization of powers adopted by Brazil with the Constitution of the Federal Republic, in 1988, which consolidate the Legislative, the Executive and the Judicial Powers, presenting their functions and predicting the interference of one power in the other.
\end{abstract}

Keywords: Powers; Brazil; Liberalism.

\footnotetext{
* Doutora em Ciência Política, Universidade Federal Fluminense. Agência de financiamento: CAPES. Contato: cienciapocamila@bol.com.br.
} 


\section{Governo e Poder}

A elaboração de uma teoria de poderes relaciona-se diretamente com o próprio desenvolvimento de uma teoria de Estado e de governo e com a forma como a sociedade vai solucionar seus conflitos.

Locke argumenta que o governo civil irá transformar a liberdade dos homens, submetendo-a à Lei. Se antes, no estado de natureza, os homens não se submetiam a qualquer poder superior na Terra, com a instituição do governo surge a autoridade Legislativa - e a liberdade fica atrelada àquilo que é elaborado por este poder. O legislativo ou os magistrados por ele nomeados são o juiz na Terra, o qual tem autoridade para resolver todas as controvérsias e reparar os danos que atinjam a qualquer membro. $\mathrm{O}$ autor menciona três poderes: o legislativo, o executivo e o federativo. O governo e o próprio contrato social existem para que haja uma delegação de poder $^{21}$.

Montesquieu analisa diferentes Constituições e reflete sobre a Constituição Inglesa. Os diferentes tipos de governo não são livres "por sua natureza" e neles é constante a ameaça de a autoridade impessoal das leis ser suplantada pela vontade pessoal de um homem ou de um grupo social. Então, somos livres onde há instituições, mas deixamos de ser quando o poder se torna violência. Sua proposta de governo moderado desenvolve-se como um freio aos abusos do poder. Como o poder pode se tornar abusivo, há que fragmentá-lo, dispondo de diferentes forças de modo que elas se anulem. Poder contra poder, assim se conseguira a verdadeira liberdade. Preocupado com as intervenções arbitrárias do Rei, o pensador argumenta por um poder julgador que não se submeta a seus arbítrios. Legislativo, Executivo e Judiciário, mantendo uma participação da nobreza, organizam sociedade ${ }^{32}$.

Para os Federalistas, Hamilton, Madison e Jay, o poder é a capacidade ou faculdade de fazer algo; e a capacidade de fazer algo é o poder de empregar os meios necessários à execução "desse algo". O governo nacional deve ser o juiz em primeira instância do exercício próprio de seus poderes e, em segunda instância, os seus membros ${ }^{43}$. A conveniência de uma lei deve ser sempre determinada pela natureza dos poderes em que ela se funda. Inspirados em

\footnotetext{
${ }^{2}$ LOCKE, J. Segundo Tratado sobre o Governo Civil. São Paulo: Martins Fontes, 2005.

${ }^{3}$ MONTESQUIEU, B. Do espírito das leis. In. Coleção Os Pensadores. São Paulo: Nova Cultural Ltda, 1999.

${ }^{4}$ HAMINTON, A; MADISON, J.; e JAY, J. Os Artigos Federalistas, 1787-1788. Rio de Janeiro, Nova Fronteira, 1993.
} 
Locke e em Montesquieu, os Federalistas argumentam pelo desenvolvimento de um Executivo, de um Judiciário e de um Legislativo Federais, ou seja, que não se restringem às esferas dos Estados.

A teoria desses autores irá influenciar diretamente a organização de poderes do Brasil contemporâneo, que menciona a existência de três poderes: Legislativo, Executivo e Judiciário, ainda que o poder seja uno e indivisível. O Brasil chegou a ter um Poder Moderador, durante o Império, mas logo foi consagrada a "teoria dos três poderes".

Entretanto, esses poderes não são separados. Eles se complementam, buscando garantir um equilíbrio social, seja a partir de questões filosóficas justificadoras do Estado e do governo, como desenvolve Locke, seja pela incorporação das forças sociais em conflito, como apresenta Montesquieu, ou pela construção de um governo forte, como escrevem os Federalistas. A pesquisa analisa e relaciona a teoria desses autores, argumentando pela existência de uma teoria da combinação dos poderes e questionando a concepção de "separação".

\section{Os Poderes}

A organização dos poderes de Locke já possui o fundamento para a posterior organização conforme fizeram Montesquieu e os Federalistas. Locke escreve sobre "poder legislativo, executivo e federativo ${ }^{54 ",}$ não tratando o Judiciário como um "poder específico". Enquanto ao legislativo é entregue a tarefa de elaborar as leis que irão reger a sociedade, julgando que castigo cabe às várias transgressões; o executivo deve garantir seu cumprimento. O indivíduo renuncia ao poder de castigar as ofensas em todos os casos que for possível recorrer à lei, excluindo-se o julgamento privado de qualquer particular. E cada julgamento das ofensas importa no seu próprio julgamento, já que é ele mesmo ou o seu representante que o faz. Está criado o governo representativo, em que alguns homens agem em nome de outros. O terceiro Poder, o Federativo, cuidará da relação do Estado com os demais Estados ${ }^{65}$.

\footnotetext{
${ }^{5}$ Locke escreve "poder, legislativo, executivo e federativo" com letra minúscula, por isto, irei manter a escrita quando me referir ao texto lockeano.

${ }^{6}$ Segundo Laslett, as referências de Locke ao poder são um complemento a suas outras declarações, não uma explicação diferente e paralela (LASLETT, P. Introdução. In: LOCKE, J. Segundo Tratado sobre o Governo Civil. São Paulo: Martins Fontes, 2005).
} 
Não há em Locke uma importância em manter os poderes em mãos distintas a fim de se preservar a liberdade e garantir os direitos. O judiciário jamais é mencionado por Locke no mesmo plano dos demais poderes, ele é um atributo geral do Estado, ainda que devesse ser imparcial e probo. Locke ignorou a controvérsia sobre a separação dos poderes surgida na história constitucional inglesa, apesar de se envolver com a mesma. "Quando Locke se refere aos diversos poderes da sociedade política, da supremacia de um deles e do caráter derivativo dos demais, é preciso tomá-lo, ao menos de início, no simples sentido de força"76. Vernière afirma que Locke não teme a confusão dos poderes, mas sim a monarquia absoluta ${ }^{87}$. Em caso de quebra de confiança, o povo resiste legitimamente aos abusos da coroa, mesmo pela violência.

Para Locke, o legislativo é o poder supremo da comunidade, é sagrado e inalterável nas mãos de quem a comunidade uma vez o colocou. E esses mesmo homens que elaboram as leis devem se submeter a elas. Também para Montesquieu o legislativo é formado por um corpo de homens que irá ditar as leis à sociedade. O poder legislativo é mais bem ordenado por muitos do que por um só. Os Federalistas, por razões distintas, acabam chegando à mesma conclusão: no governo republicano, a autoridade legislativa predomina necessariamente.

Os Federalistas sustentam que as funções propriamente pertencentes a um poder não devem ser direta e completamente administradas por nenhum dos outros dois poderes. Nenhum deles deve possuir uma influência dominante sobre os outros na administração de suas respectivas autoridades. Baseiam-se em Montesquieu que, por sua vez, baseou-se em Locke, que viveu a Inglaterra das mudanças, a qual foi o objeto de análise de Montesquieu e, em certo sentido, de crítica dos Federalistas. Montesquieu viu a Constituição Inglesa como padrão, como o espelho da liberdade política e Madison argumenta que nela os poderes legislativo, executivo e judiciário não são totalmente independentes e distintos entre si.

Segundo a Constituição inglesa, o magistrado executivo é parte integrante do poder legislativo e detém sozinho a prerrogativa de fazer tratados com soberanos estrangeiros, os quais, quando feitos, têm, sob certas licitações, a força de atos legislativos. Todos os membros do judiciário são designados por ele, podem ser removidos por ele por solicitação das duas Câmaras do Parlamento, e compor, quando convier ao magistrado executivo consultá-los, um

\footnotetext{
${ }^{7}$ LASLETT, P., Op. Cit., p. 173.

${ }^{8}$ VERNIÈRE, P.. Dois planos e Duas Leituras. In: QUIRINO, C.; SOUZA, M. (Orgs) O Pensamento Político Clássico. São Paulo: Biblioteca Básica de Ciências Sociais, 1992.
} 
de seus conselhos constitucionais. Uma das câmaras do poder legislativo forma também um grande conselho constitucional para o chefe executivo, sendo também, por outro lado, o único depositário do poder judiciário em casos de impeachment e estando investido de suprema jurisdição de apelação em todos os demais casos. Além disso, os juízes estão tão intimamente ligados ao poder legislativo que, frequentemente, assistem às suas deliberações e delas participam, embora sem direito ao voto legislativo.

Os Federalistas criticam a forma como os poderes intervêm um no outro conforme a Constituição inglesa, mas admitem que deve haver algum tipo de interferência. Sustentam que Montesquieu não queria dizer que os poderes não devem ter nenhuma ingerência parcial, ou nenhum controle sobre os atos uns dos outros, mas sim que quando todo o poder de um braço é exercido pelas mesmas mãos que possuem todo o poder de outro, os princípios fundamentais de uma constituição livre estão subvertidos. No caso da Inglaterra, o rei não poderia ter o poder legislativo e a administração suprema da justiça, por exemplo. $\mathrm{O}$ magistrado não pode fazer uma lei, mas pode vetá-la, nem administrar a justiça, embora possa designar os que a administram. Os juízes não podem exercer nenhuma prerrogativa executiva, nem qualquer função legislativa, embora possam ser aconselhados por conselhos legislativos. O conjunto do legislativo não pode desempenhar ato judiciário, mas a ação conjunta de suas câmaras pode remover os juízes de seus cargos, embora uma das câmaras possua o poder judicial em última instância. E, também, o conjunto legislativo não pode exercer prerrogativa do executivo, embora uma de suas câmaras constitua a suprema magistratura executiva. Os poderes devem ser mantidos tão separados e independentes uns dos outros quanto o admita a natureza de um governo livre, ou na medida em que é necessário.

Os Federalistas afirmam, então, que os poderes são vinculados e misturados o suficiente para que cada um tenha um controle constitucional sobre os outros, o grau de independência exigido pela máxima como essencial a um governo livre jamais poderá ser devidamente mantido na prática.

Se, por um lado, Montesquieu sustenta que tudo estaria perdido se o mesmo homem ou corpo de principais ou nobres ou o povo exercesse os três poderes; por outro lado, não são poucas as intromissões de um poder em outro, inclusive para garantir os limites. Montesquieu conclui que, nas monarquias de seu tempo, os três poderes não são divididos e calcados no modelo da constituição inglesa. Cada um possui uma divisão particular, aproximando-se mais ou menos da liberdade política. Ao referir-se aos antigos, afirma que eles não poderiam ter 
uma ideia correta da monarquia, pois não conheciam a divisão dos três poderes no governo de um só. Comparando os gregos com as monarquias atuais, conclui que os três poderes, para aqueles, estavam divididos de maneira que o povo tinha o poder legislativo e o rei, o executivo e o de julgar, enquanto nas monarquias de seu tempo, o príncipe possui o poder executivo e o legislativo, mas não julga.

A teoria dos Três Poderes que é atribuída a Montesquieu partiria da premissa que um poder iria controlar o outro, um servindo de barreira às ambições dos outros. Todavia, uma análise da teoria nos permite perceber que esses poderes acabariam mais por se permear e se confundir, ao invés de se separar. Montesquieu pretende analisar o conjunto das condições que contribuem para determinar o destino das sociedades e de sua legislação. Defendendo o governo moderado, sustenta que para que esse seja formado, é mister combinar os poderes, regulamentá-los, moderá-los e fazê-los agir; oferecer um lastro a um para colocálo em condição de resistir a outro. Por isso, uma combinação entre eles. Sua preocupação é o despotismo que, na verdade, é a ausência de leis. E isso se dá porque Montesquieu crê que a violência só poderá ser contida por meio de leis. Locke possui esse mesmo raciocínio: para evitar a guerra, são necessárias leis escritas.

Para que não haja despotismo, o governo precisa ser moderado. A liberdade só existe em Estados moderados - e isso, para o pensador francês, significa a existência de um poder controlando o outro, impondo-lhe limites e impedindo que haja abuso. Para que não se possa abusar do poder, é preciso que, pela disposição das coisas, poder freie poder. Ou seja, é pela estrutura do poder que o poder será freado, é pela imposição de limites, em certo sentido, externos ao próprio poder. Montesquieu não faz apelo aos bons sentidos dos homens, conta apenas com forças cuja tendência espontânea seria a violência. Preocupa-se em equilibrar as tensões, encontra uma "máquina regulada", como um sistema de pesos e contrapesos. Ao mesmo tempo que os poderes precisam agir, que um possa resistir ao outro, eles devem ser controlados. Para ter esse sistema de pesos e contrapesos, o sistema legal deve ser estável o bastante por si mesmo. A lei saberá equilibrar as forças e deve-se desejar a ponderação.

Os Federalistas seguem nessa mesma linha. Madison sustenta que o poder é abusivo por natureza e que deve ser efetivamente impedido de transpor os limites a ele atribuídos. E que o acúmulo de todos os poderes, legislativo, executivo e judiciário, nas mãos, seja de uma pessoa, de algumas ou de muitas, seja hereditário, autodesignado ou eletivo, pode ser considerado tirania. E argumenta que a mera demarcação no papel dos limites constitucionais 
dos vários poderes não é uma salvaguarda suficiente contra aqueles abusos que levam a uma concentração tirânica de todos os poderes de governo nas mesmas mãos.

Essa é a base do sistema de Montesquieu, o poder corrompe e, por isso, precisa de limites. E mesmo de Locke, que entende que os indivíduos devem entregar seus poderes ao governo. É a preocupação com o poder e com quem ele se encontra e a possibilidade de ameaças que vem de seu uso que motiva os pensadores a escrever. Assim, para manter na prática a necessária divisão do poder entre os vários braços do governo, como as medidas externas se mostram inadequadas, deve-se sanar a falha arquitetando de tal modo a estrutura interna do governo que suas várias partes constituintes possam ser, por suas relações mútuas, instrumentos para a manutenção umas das outras em seus devidos lugares.

Primeiramente, as medidas externas a que Madison se refere tratam do controle do povo sobre os poderes. Segundo ele, se, por um lado, há argumentos para manter uma via constitucional para a decisão do povo em determinadas ocasiões importantes e extraordinárias, por outro lado, há objeções contra o apelo ao povo como medida usual para manter os vários poderes dentro de seus limites. Rebatendo a proposta de realização de uma convenção para alterar a Constituição ou corrigir infrações dela sempre que dois ou três braços do governo coincidirem, Madison faz algumas críticas ao chamamento do povo. Preocupa-se com a não perturbação da tranquilidade pública pelo estímulo excessivo das paixões públicas, daí seu receio em entregar ao povo a tomada de decisões. Madison sustenta que o recurso ao povo a intervalos fixos parece quase tão inaceitável como o recurso a ocasiões especiais, à medida que se apresentem.

Assim, os poderes devem ser independentes e distintos, entretanto, como a execução desse princípio acarretaria algumas dificuldades e certa despesa adicional, alguns desvios devem ser admitidos. Madison, com isso, parece reconhecer um princípio puro, com falhas na aplicação prática, o que faz exigir a interferência de um poder no outro. Todavia, Madison, ao analisar Montesquieu, reconhece que a própria teoria de Montesquieu não é uma separação mas uma mistura, o que afastaria a noção de um princípio puro sem aplicação prática. De toda forma, após a análise acerca do poder nas três teorias propostas, um poder interfere no outro.

Mas o que leva Madison a sustentar que não é viável uma "separação dos poderes" na prática? 


\begin{abstract}
povo, através de canais que não tivessem nenhuma comunicação entre si. (...) $\mathrm{Na}$ organização do poder judiciário, em particular, poderia ser inconveniente insistir no princípio com rigor; primeiro porque, sendo essencial que os membros possuam certas qualificações, a preocupação básica deveria ser encontrar o modo de escolha que melhor assegura tais qualificações; segundo, porque o caráter permanente dos cargos nesse poder não pode deixar de anular em pouco tempo todo o sentimento e dependência para com a autoridade que os conferiu ${ }^{98}$.
\end{abstract}

Assim, a grande garantia contra uma concentração gradual dos vários poderes no mesmo braço consiste em dar aos que administram cada poder os meios constitucionais necessários e os motivos pessoais para resistir aos abusos dos outros. A ambição deve poder contra-atacar a ambição. Ora, isso seria a mesma noção de um poder contra o outro, de Montesquieu. Madison sustenta que o interesse deve estar vinculado aos direitos constitucionais do cargo e que esses estratagemas são necessários para o controle dos abusos do governo. Há ingerência de um poder no outro poder e é essa interferência que tende a controlar os abusos.

Diante disso, a afirmação de Hamilton de que todas as observações fundadas no risco da usurpação devem ser referidas à composição e estrutura do governo, não à natureza ou extensão de seus poderes. Um governo deve conter em si mesmo todo o poder necessário à plena realização das finalidades que lhe foram atribuídas e à completa execução dos encargos que lhe foram confiados, livre de qualquer controle além da consideração pelo bem público e pela opinião do povo.

Mas se Montesquieu tinha receio do despotismo relacionado aos Reis, os Federalistas já falam de um outro despotismo: o despotismo eletivo. O fato de os poderes serem exercidos por uma pluralidade de mãos e não por uma mão única não melhora em nada, segundo Madison.

Quanto a isso, é possível pensar duas questões: uma, que o receio dos Federalistas é o povo; outra, que, mesmo com eleições, é possível o despotismo. Já não se fala em poder do Rei ou em nobreza, como pensavam Locke e Montesquieu, mas continua o outro motivo da retirada dos poderes em estado de natureza, ou seja, impedir que todos sejam reis e, assim, a propriedade seja ameaçada. Da mesma forma, não há uma nobreza, mas a ameaça vinda do povo, de suas paixões, de sua "tolice" que precisa ser controlada pelos representantes e mesmo pelos outros poderes. Se a ameaça "de cima" deixou de ser preocupação em função da redistribuição do poder, a ameaça com os de "baixo" parece que permanece, aí outra

${ }^{9}$ HAMINTON, A; MADISON, J.; e JAY, J. Op. Cit., p. 349 
redistribuição do poder - agora concentrado na nação. A preocupação com o despotismo eletivo relaciona-se com os avanços sobre a propriedade que os legislativos estaduais e os novos homens que começam a chegar ao poder cometem. E não com uma simples dominação da maioria.

Os Federalistas defendem a moderação, o que também Montesquieu defendia. A Inglaterra, nação que foi criticada pelos Federalistas, foi o exemplo de governo moderado que Montesquieu encontrou. Independentemente de como vivem os ingleses, Montesquieu dedicase aos estudos das leis inglesas. A liberdade que Montesquieu encontra, está na constituição e não na "realidade". No Direito, e não nos fatos. Ele analisa como a constituição inglesa agencia os diversos poderes, para garantir a liberdade do cidadão, enquanto a Inglaterra real é motivo de disputas dos próprios historiadores ingleses.

\begin{abstract}
O grande mérito de Shackleton é o de ter revelado de forma definitiva, que a viagem de Montesquieu à Inglaterra coincidia com uma vigorosa contestação sobre a interpretação da constituição. De um lado, os partidários do Estado misto (mixed state) propunham o exercício conjunto do poder legislativo, concebido como natural e proeminente, pelo rei, os nobres e o povo, de acordo com um equilíbrio harmonioso. De outro lado, os partidários da separação dos poderes (balance of powers) acreditavam garantir a liberdade com uma divisão dos poderes, concebidos como funções diferentes, e atribuídos a corpos ou a indivíduos diferentes ${ }^{109}$.
\end{abstract}

Althusser, analisando Eisenmann ${ }^{1110}$, sustenta que a teoria e Montesquieu teria engendrado um mito - o mito da separação dos poderes ${ }^{1211}$. Segundo esse mito, deveriam existir três poderes: o executivo, formado pelo rei e seus magistrados, o poder legislativo, formado pela câmara baixa e a câmara alta, e o poder judicial, formado por um corpo de magistrados. Cada poder teria uma esfera própria, sem interferência, e seria assegurado em cada esfera por um órgão rigorosamente distinto dos outros órgãos. Não se poderia conceber nenhuma interferência de um poder no outro. Althusser aponta que Eisenmann teria mostrado que não existia, em Montesquieu, essa teoria, ao menos não da forma como tem sido apresentada. E argumenta que: 1) o executivo interfere no legislativo, porque o rei goza do direito de veto; 2) o legislativo pode, em certa medida, exercer um direito de vigilância sobre o executivo, pois controla a aplicação das leis que votou e pode pedir contas aos ministros

\footnotetext{
${ }^{10}$ VERNIÈRE, Op. Cit., p. 334.

${ }^{11}$ EISENMANN, C. L'Esprit des Lois et la séparation des pouvoirs. In: MALBERG, R. Mélanges. Paris: Sirey, 1933, p. 133-160.

${ }^{12}$ ALTHUSSER, L. Montesquieu, a Política e a História. Lisboa: Editorial Presença, 1972.
} 
perante o Parlamento; 3) o legislativo interfere seriamente no judicial, pois erige um tribunal em três circunstâncias, quais sejam: no caso de matérias em que os nobres são julgados pelos seus pares, em matéria de anistia (para corrigir a lei) e em matéria de processos políticos, em que a câmara baixa acusa perante a câmara alta.

Ainda, Eisenmann teria mostrado que Montesquieu pensava em combinação, fusão, ligação, dos poderes e não "separação", termo que é utilizado para definir sua teoria. Para compreender essa afirmação Eisenmann teria argumentado que o poder judicial não é um poder no sentido próprio, posto que é invisível, nulo. Althusser entende que Montesquieu transfere o que o judicial poderia ter de efeitos políticos para órgãos propriamente políticos, restando para o judicial algo nulo politicamente. Nesse sentido, estaríamos em face de dois poderes, o executivo e o legislativo. Mas três potências, que são o rei, a câmara alta e a câmara baixa, isto é, o rei, a nobreza e o povo. Montesquieu, então, teria como objetivo combinar as três potências. Trata-se de um problema político de relações de forças e não de um problema jurídico relativo à definição da legalidade e das suas esferas.

Althusser, portanto, sustenta que estaria esclarecido o problema do governo moderado. "A verdadeira moderação não é nem a estrita separação dos poderes nem a

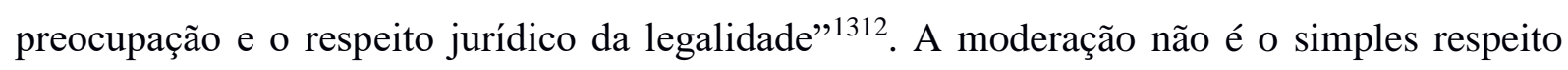
pela legalidade, é o equilíbrio dos poderes, isto é, a divisão dos poderes entre as potências, e a limitação ou moderação das pretensões de uma potência pelo poder das outras. A "famosa" separação dos poderes é a divisão ponderada do poder entre potências determinadas: o rei, a nobreza e o povo.

Mas, por que é feita essa divisão? Althusser propõe-se a denunciar um último mito: o de que haveria uma divisão e um equilíbrio. Em Montesquieu há interferências de um poder sobre outro, algumas combinações e interferências são possíveis e outras não. Althusser busca entender o que está excluído na teoria de Montesquieu e chega a algumas conclusões.

A primeira combinação excluída, segundo Althusser, é que o legislativo possa usurpar os poderes do executivo, pois viraria despotismo, ao passo que o inverso não é verdadeiro. Desse modo, Montesquieu admitiria que a monarquia existiria mesmo que o rei detivesse o poder executivo e o legislativo. Mas quando o povo é príncipe, tudo está perdido.

A segunda combinação excluída diz respeito à detenção do judicial pelo executivo, pelo rei. Ou seja, o rei não pode julgar. E o exemplo citado por Montesquieu é o de Luis XIII

\footnotetext{
${ }^{13}$ ALTHUSSER, L, Op. Cit., p. 134.
} 
querendo julgar a um nobre. Essa cláusula particular interessa à proteção dos nobres contra o arbítrio político e jurídico do príncipe. Se pensarmos nas forças reais que existem no momento em que Montesquieu escreve, é a nobreza que ganha com o seu projeto; ganha enquanto classe, pois se torna uma força política reconhecida na câmara alta; ganha por se tornar um classe cujo futuro pessoal, a posição social, os privilégios e as distinções são garantidos contra as violências do rei e do povo, por meio de "medidas de proteção". "Na sua vida, nas suas famílias e nos seus bens, os nobres estarão ao abrigo tanto do rei como do povo. Não se poderia garantir melhor as condições de perenidade de uma classe decadente a quem a história arrancava e disputava já as suas antigas prerrogativas"1413.

Ainda, Althusser evidencia qual a certeza que cabe ao rei, segundo a teoria de Montesquieu: o monarca será protegido pela defesa social e política da nobreza contra as revoluções populares. É essa nobreza que estará com ele, contra o povo. Essa nobreza servirá de contrapeso ao povo, pois com uma representação sem proporção com o número e o interesse da maioria, equilibrará a representação do povo no legislativo. Essa nobreza ensinará ao povo que as grandezas são respeitáveis, que existe uma estrutura no Estado.

Vernière ${ }^{1514}$ questiona-se se deveríamos destruir a ideia de um equilíbrio, de um "balanço" dos poderes, para retomar a teoria do governo misto que reconstitui a unidade dos poderes. Este poder único seria distribuído entre o monarca, a Câmara dos Lordes e a dos Comuns. A Inglaterra seria uma mistura de monarquia, aristocracia e democracia. E concorda com Eisenmann que Montesquieu pensa na hipótese de uma sociedade de classes, ou de estamentos: as vilas, os campos, as universidades, os nobres, compõem o Parlamento britânico e a realidade social reflete-se na divisão do poder. Segundo Vernière, para Montesquieu não existiria "divisão do poder", mas "repartição dos poderes"; o equilíbrio nasceria de uma tensão; a harmonia nasce do conflito superado, pois a vida impõe movimento.

Mas aqui cabe uma questão que, em certo sentido, intrigou Althusser e é fundamental para esclarecer alguns pontos. O que é o povo? Quem é o povo? Até porque são sociedades distintas, a Inglaterra de Locke, a França de Montesquieu e mesmo a Inglaterra de Montesquieu, ou a "América" dos Federalistas. A noção de burguesia, nesses tempos, é bastante discutida, já que ela está incluída na concepção de "povo" - posto que não é nem rei

\footnotetext{
${ }^{14}$ ALTHUSSER, L, Op. Cit., p. 138.

${ }^{15}$ VERNIÈRE, Op. Cit.
} 
nem nobreza. Entretanto, é questionável afirmar que essa burguesia estaria contrária à própria nobreza.

Althusser escreve que a literatura política do século XVIII foi dominada pela ideia de que a monarquia absoluta estabeleceu-se contra a nobreza e que o rei teria se apoiado nos plebeus para equilibrar o poder dos seus adversários feudais. É a discussão entre germanistas (Saint-Simon, Boulainvilliers e Montesquieu) e dos romanistas (o Abade Dubos). Os germanistas evocam com nostalgia os tempos da monarquia primitiva - um rei eleito pelos nobres, para opor à monarquia absoluta; e o partido absolutista de inspiração "burguesa", os romanistas e os enciclopedistas celebram o ideal do príncipe que sabe preferir os méritos e os títulos da burguesia laboriosa às pretensões caducas dos senhores feudais.

Ao escrever sobre a burguesia do século XVIII, Althusser esclarece que não se deve projetar à burguesia daquele século a imagem da burguesia atual. A burguesia moderna que revolucionou a ordem econômica e social é a burguesia industrial, com a sua economia de produção em massa, que reinveste na produção, que era desconhecida no século XVIII. A burguesia deste século repousava nos seus elementos mais avançados sobre a economia mercantil. Essa economia mercantil era uma peça suficientemente integrada no próprio sistema feudal, o mercantilismo é a política e a teoria dessa integração. Toda a atividade econômica que pareceria vanguarda está concentrada no aparelho de Estado ${ }^{1615}$, submetida aos seus lucros e às suas necessidades. Na sua estrutura, o circuito econômico desse tempo é orientado tendo como fim o aparelho de Estado. Os "burgueses", que dão vida a essas operações econômicas, não têm outro horizonte econômico e pessoal senão a ordem feudal que serve a esse aparelho de Estado.

\begin{abstract}
Uma vez rico, o comerciante não investe, com raras exceções, os seus benefícios na produção privada, mas em terras que compra para conseguir um título e entrar na nobreza; em ofícios, que são funções de administração, que compra para usufruir dos seus lucros como se fossem uma renda; e em empréstimos de Estado que lhe asseguram grandes benefícios ${ }^{1716}$.
\end{abstract}

Logo, o fim da burguesia enriquecida pelo negócio consiste em voltar a entrar diretamente na sociedade, na nobreza ou diretamente no aparelho de Estado ou nos lucros do aparelho de Estado por meio das rendas. Essa burguesia ascendente toma lugar entre a

\footnotetext{
${ }^{16}$ Sobre a expressão aparelho de Estado, ver ALTHUSSER, L. Aparelhos ideológicos de Estado. São Paulo: Graal, 2003.

${ }^{17}$ ALTHUSSER, L. Montesquieu, a Politica e a História. Lisboa: Editorial Presença, 1972, p. 148.
} 
nobreza que não combate e sustenta a ordem tanto quanto a agita. Todo o circuito da sua atividade econômica e da sua história pessoal continua inscrito nos limites e nas estruturas do Estado feudal.

Ao analisar duas tentativas ${ }^{1817}$ de resposta sobre qual a natureza e a função da monarquia absoluta, Althusser aproxima-se da interpretação de Porchnev. Baseado nesse autor, Althusser argumenta que a monarquia absoluta não é o fim nem prossegue o fim do regime de exploração feudal, mas constitui o aparelho político indispensável; o que se modifica com a monarquia absoluta é a forma de dominação política. Essa transformação política corresponde à mudança das condições da atividade econômica realizada no próprio seio do regime feudal e, em particular, ao desenvolvimento da economia mercantil, ao aparecimento de um mercado nacional. A monarquia absoluta é uma nova forma política requerida para manter a dominação e a exploração feudais no período de desenvolvimento da economia mercantil.

Que os senhores feudais pensem que o aparecimento da monarquia absoluta, a centralização e seus epifenômenos tenham tomado o aspecto de uma usurpação, de injustiça e de violência contra eles, segundo Althusser, não é espantoso, mas isso lhes ocultava a realidade, porque o rei da monarquia absoluta representava os interesses gerais do feudalismo, inclusive contra os protestos dos senhores feudais atrasados pela nostalgia e cegueira. Se o rei fosse árbitro, seria o dos conflitos internos do feudalismo.

Althusser salienta, então, a intervenção de uma outra potência diferente da que Montesquieu faz figurar na divisão do poder: a potência da massa do povo sobre quem se exercia a exploração feudal que o aparelho de Estado da monarquia absoluta tinha por função manter e perpetuar. $\mathrm{O}$ antagonismo fundamental não opunha a monarquia absoluta aos senhores feudais nem a nobreza à burguesia que na sua totalidade se integrava ao regime de exploração feudal e dele se aproveitava, mas o próprio regime feudal às massas submetidas à sua exploração. Entre o rei, a nobreza e a burguesia, havia um conflito político e ideológico; entre a massa dos explorados camponeses submetidos aos direitos feudais, pequenos artistas, lojistas, pequenos ofícios das cidades e a ordem feudal e o seu poder político tratava-se de violência. As revoltas de fome eram numerosas nas cidades e nos campos em todo o século XVII francês e a repressão era impiedosa.

\footnotetext{
${ }^{18}$ Sobre a primeira tentativa, ver ALTHUSSER, L. Op. Cit., p. 149.
} 
A razão da massa do povo estar ausente dos contratos que lhe dizem respeito é o fato desses contratos estarem interessados em mantê-la ausente ou em consagrar sua servidão. Então, as forças sociais são: rei, nobreza, burguesia e povo. Althusser sustenta que, longe de ser o arauto da burguesia, essa câmara baixa representava a parte entregue a uma burguesia que procurava o seu lugar na ordem feudal e, tendo-o encontrado, já não pensava em ameaçar essa mesma ordem.

A análise de Eisenmann e, em seguida, de Althusser, evidenciando o entrelaçamento de poderes é próxima da proposta política dos Federalistas que, ao analisar a obra de Montesquieu, também teriam compreendido um entrelaçamento de poderes e não uma “divisão". Nesse sentido, a crítica dos Antifederalistas, acusando os Federalistas de traição à Constituição ao propor a interferência de um poder no outro, ainda que tenha fundamento, posto que era isso mesmo que eles faziam, não poderia incidir sobre uma análise distorcida da teoria dos poderes de Montesquieu.

Com os Federalistas, a noção de mistura de poderes organizados para manter a ordem fica mais evidente e não deixa dúvida de que não há uma separação como se pode pensar e como se tornou comum sustentar com a conhecida expressão "Separação dos Poderes". Por trás dela estava a ideia de governo misto, que buscava equilibrar as forças sociais a fim de evitar governos extremistas (tal qual pensou Aristóteles ${ }^{1918}$ ). Assim, a noção de liberdade era definida segundo a divisão das funções do governo e o equilíbrio dos grupos sociais. Ficou evidente que a separação dos poderes é adotada pelos Federalistas com a intenção de barrar a democracia radical e frear as medidas dos legislativos estaduais, ou seja, para tirar ou diminuir poder do legislativo, ou melhor, dos homens novos que estavam indo para a política e participando dos legislativos estaduais.

Madison chegou a defender a redução do poder legislativo pela partilha, com outros setores do governo, do poder de legislar, já que nos Estados Unidos da América a principal ameaça à liberdade vinha deste poder. Segundo Kramnick ${ }^{2019}$, o objetivo de barrar os anseios populares é tão grande que Morris defende a necessidade de um senado para controlar a precipitação, a mutabilidade e os excessos da primeira Câmara. Hamilton sugere que os senadores sejam vitalícios. Entende-se, também, o motivo da defesa fervorosa do poder de veto do presidente, ou mesmo a defesa de atribuir ao judiciário funções legislativas: os

\footnotetext{
${ }^{19}$ ARISTÓTELES. A Política. In: ARISTÓTELES, Coleção Os Pensadores. São Paulo: Nova Cultural, 1999.

${ }^{20}$ KRAMNICK, I. Introdução. In HAMINTON, A; MADISON, J.; e JAY, J. Os Artigos Federalistas, 17871788. Rio de Janeiro: Nova Fronteira, 1993.
} 
tribunais devem manter o legislativo dentro dos limites de seu poder. A flexibilização da "separação dos poderes" ocorre para sua própria proteção, ou melhor, para proteger a propriedade e evitar as reivindicações populares. É por isso que os Antifederalistas criticaram a "separação de poderes" feita pelos Federalistas, que acabava por dar muito poder ao presidente e ao judiciário, e afirmavam que a Constituição criava muito mais um governo misto, de poderes partilhados, de controles e equilíbrios que de separação.

A Constituição de 1787 consagra a teoria dos "Três Poderes" elaborada por Montesquieu. $\mathrm{O}$ documento feito pelos americanos evidencia uma preocupação com as forças sociais e com os abusos do poder legislativo. Os Federalistas foram considerados modernistas liberais e os Antifederalistas, comunitaristas nostálgicos, por isso a afirmação de que se trata da confrontação de Locke e Rousseau ${ }^{2120}$. A tendência Federalista era criar uma "América" em termos amorais, como uma nação aumentada, que ultrapassou a comunidade local e a convicção moral como base da política, uma América individualista, competitiva, preocupada com direitos privados e autonomia pessoal - esta visão está muito ligada às ideias de Madison. Ele exaltou as facções e interesses heterogêneos, afirmando que a multiplicação de religiões, interesses econômicos, facções e partidos garantiria a liberdade e a justiça americanas; e o lugar dessa diversidade cabia aos interesses econômicos. O governo seria um juiz neutro entre interesses e competição; e a justiça significava o respeito aos direitos privados, especialmente à propriedade. Madison realiza a aceitação da sociedade liberal moderna. Hamilton afirma que a prosperidade do comércio é a mais útil e produtiva fonte de riqueza nacional e, ainda que soubesse que essa valorização da recompensa pessoal contrariasse os ideais antigos de virtude cívica e obrigação pública, defendeu-a como argumento para a criação do exército federal permanente, uma vez que, com sociedade de mercado, a América não pode depender de uma milícia.

Há algo que unifica as três teorias: a preocupação com as massas populares e sua intervenção no poder político. A preocupação com a propriedade, em especial, dos que têm muito a perder. Se a noção de um poder do povo já aparece nas teorias, isso reflete os conflitos sociais que ocorreram ao longo dos tempos. Pensando contra o monarca, Locke fortalece o legislativo. Pensando contra o despotismo, Montesquieu busca limitar o poder, mas por meio do próprio poder, e isso o faz entregando o poder de moderar a uma câmara

\footnotetext{
${ }^{21}$ KRAMNICK, I, Op. Cit.
} 
formada de nobres. Pensando contra o excesso de liberdade, os Federalistas criaram um governo nacional, distante da participação popular.

A existência de duas câmaras, tanto para Montesquieu como para os Federalistas, relaciona-se com essa preocupação em barrar os anseios populares. O fundamento último é o mesmo, ainda que elas apresentassem, na aparência, motivações distintas. Montesquieu atribui à parte do corpo legislativo que é formada de nobres, a câmara alta, a capacidade de ser um poder regulador para moderar tanto o poder legislativo quanto o poder executivo. Os limites que Montesquieu defende, a moderação do governo, são justamente um atributo da nobreza, por meio do poder legislativo. Mas, enquanto Locke buscou conter o legislativo com o executivo e, mais ainda, com o direito de resistência do povo, os Federalistas, apoiados em Montesquieu, buscam conter o legislativo por ele mesmo, uma vez que não acreditam - ou não querem acreditar por medo de perder a estabilidade - na possibilidade de o povo, mesmo que por convenções, barrar o governo. Do que se segue que os Federalistas dividem o legislativo em duas câmaras, com características um tanto distintas, ou seja, com diferentes modos de eleição e diferentes princípios de ação, pouco vinculados um com o outro quanto o permitam a natureza de suas funções comuns e sua dependência comum da sociedade. Mas não há uma Câmara de Nobres e, sim, um Senado, que seria formado por representantes dos diferentes Estados e garantiria uma intervenção igual a dos Estados na Federação. Assim como o peso do legislativo requer que ele seja dividido, a debilidade do executivo pode exigir seu fortalecimento. $\mathrm{O}$ poder absoluto de veto sobre os atos do legislativo parece ser a defesa natural de que o magistrado executivo deveria estar armado a fim de barrar os abusos do legislativo.

Os Federalistas propõem, ao rebater as críticas dos Antifederalistas, um projeto de poder legislativo - que é quase a teoria de Montesquieu por completo. Já não analisam o poder legislativo em diferentes formas de governo, deixando claro que sua proposta política é a república e um legislativo formado por duas câmaras. Mas diferenciam democracia e república. Uma democracia pura, segundo Madison, é uma sociedade formada por um pequeno número de cidadãos que se unem e administram pessoalmente o governo. Ela não dispõe de nenhum remédio contra os malefícios da facção, uma paixão ou interesse comum contamina, em quase todos os casos, a maioria do todo. A própria forma de governo propicia a comunicação e o ajuste e nada controla as tendências a sacrificar a parte mais fraca ou um indivíduo inofensivo. Uma república, por sua vez, é um governo em que está presente a 
representação. O governo é delegado a um pequeno número de cidadãos eleitos pelos demais. Pode se exercer sobre um maior número de cidadãos e um território mais extenso que um governo democrático e isso torna as combinações facciosas menos temíveis. A república quer extraia seu poder direta ou indiretamente do povo, "é administrada por pessoas que conservam seus cargos enquanto são aprovadas e por um período limitado, ou enquanto exibem bom comportamento". Madison sustenta que é essencial que o poder emane da grande maioria da sociedade e não de uma proporção insignificante ou de uma classe favorecida.

\section{A Combinação}

No Estado, os "poderes" se combinam para conseguir atingir seus objetivos. Ou seja, não há uma "separação" de poderes, uma "divisão", há um entrelaçamento de poder, uma combinação a fim de se organizar a ordem. Para Locke, existem os poderes: legislativo - o supremo -, o executivo e o federativo; para Montesquieu e os Federalistas, existem os poderes: Executivo, Legislativo e Judiciário. Mas a noção de um poder julgador já está presente em Locke, de modo que não se poderia dizer que o "poder judiciário" apareceria somente em Montesquieu.

Locke entende que o poder federativo estaria nas mesmas mãos do executivo, e que seria melhor que o legislativo não estivesse nas mesmas do poder de executar. Assim, para o inglês, o rei, que seria "o executivo", e o corpo de homens, que seria "o legislativo", conseguem entrar em equilíbrio: Locke não faz referência a uma classe específica, ainda que reforce a importância da riqueza e seu contrato sirva mais aos que têm que aos que não têm propriedade de bens.

Tal qual Locke, Montesquieu também acaba por entregar a um poder as funções de outro. O francês reforça o papel da nobreza enquanto um corpo intermediário capaz de proteger o rei do povo e o próprio povo dele mesmo: Montesquieu defende o governo moderado e é a nobreza a responsável pela moderação - e ela existe em sociedades baseadas na distinção, ou seja, em monarquias. A nobreza estaria no legislativo, mas a ela também restaria um poder de julgar. E o rei, além de executar, teria o poder de veto, mostrando uma clara intervenção na elaboração das leis. 
Próximos a Montesquieu e seguindo sua leitura, os Federalistas já deixam evidente a noção de governo misto, de entrelaçamento de poder a fim de que os poderes possam funcionar. Acreditando na impossibilidade prática de uma separação dos poderes, argumentam pela sua combinação.

Os Federalistas não podiam pensar ou argumentar como Locke e Montesquieu em favor de uma diferença de participação entre as classes sociais no governo, ainda que o fizessem e ainda que as colônias mantivessem muitos homens excluídos do sufrágio. Não lhes era possível e, talvez, nem necessário que falassem em Rei ou em governos hereditários: por razões históricas, era preferível um governo de comerciantes, aqueles que sabem "melhor" discernir os desejos e o que é melhor para a sociedade. Esses comerciantes serão eleitos em função do mérito, ou seja, porque são "melhores". Se são comerciantes, são os que melhor sabem sobre o comércio, sobre milícias e tributos. O desenvolvimento do comércio trouxe novos problemas, administrá-los é tarefa do governo. Não há reis, não há nobres, mas há proprietários, há comerciantes. É um estado unitário, mas com uma grande milícia e burocracia. Além dos governos nos Estados, há outro governo, ainda mais distante das massas populares. Para isso é criado um governo central e a "grande nação americana".

São diferentes de Montesquieu, que se preocupava com o nascimento, com aquilo que vem de família, com a nobreza. São contextos e sociedades distintas, logo, são outras preocupações. E não são as mesmas soluções, ainda que sejam um tanto próximas. O que antes se dava por nascimento, o que fazia alguém ser "diferente" - e superior - a outrem, os títulos de nobreza que pareceram tão estranhos aos Federalistas, são substituídos por qualidades individuais, pelo mérito, pelas conquistas "de cada um".

Para Locke, Montesquieu e os Federalistas, o povo não deve ter, em si, nenhum dos três poderes, ainda que o poder emane dele. O executivo está com o Rei ou o chefe do executivo, o legislativo concentra-se em um corpo de homens, ou então, em “dois" corpos de homens, e o judiciário, em juízes destacados do povo (se para Montesquieu eles são temporários, para os Federalistas eles são vitalícios). A maioria do povo não detém em si nenhum poder, ainda que participe na "escolha" dos que terão o poder e que seja apontado como soberano, ou como a fonte do poder. O povo saberá escolher "quem é o melhor" para lhe governar. E é esse o seu papel. E, existindo o governo, há que respeitá-lo.

Mas, ainda que acreditem que o governo conseguirá pôr ordem na sociedade, entendem que é possível existir um governo que contrarie os motivos de sua criação e que 
usurpe o poder. E, nesse sentido, para "restabelecer" o que estava organizado, para manter um governo legítimo, para que o governo exerça a função para a qual foi criado, Locke afirma que é possível resistir. Caso o poder seja exercido de maneira diferente daquela que o povo escolheu, não lhe restaria outra opção a não ser a resistência, a insurreição, a revolta ou a revolução. Ou seja, uma alternativa contra o governo estabelecido que já não converge com os motivos de seu estabelecimento.

É interessante ver esse aspecto da teoria de Locke: o fato de estar num contexto de mudanças, de oposição a uma teoria que defendia o poder patriarcal do Rei, Locke acaba sendo, em alguns pontos, mais "progressista" ou mesmo revolucionário que Montesquieu. O direito de resistência, as críticas a um soberano que não cumpre o seu papel, a defesa da transformação, possuem um lugar de destaque na teoria de Locke. Enquanto Locke parece ser um avanço, em que pese alguns aspectos conservadores, Montesquieu parece ser o misto de um representante de uma sociedade em ruínas, a monarquia francesa, com uma sociedade "em transformação", a monarquia inglesa. Diante disso, a defesa, por um lado, da nobreza, da existência de corpos intermediários e, por outro lado, de um sistema de leis que critica a tortura e busca proteger os acusados; o receio com relação à igualdade e a preocupação em se diferenciar as classes, dando mais poder às classes altas e, ao mesmo tempo, a importância em se tirar o povo da prostração e não deixar que sejam escravos civis e políticos.

O receio com relação ao povo é evidente, mas ele já não é excluído da política, ou melhor, ele é soberano. Locke, Montesquieu e os Federalistas defendem o sistema representativo e o fazem por ser-lhes útil, para que a ordem que defendem permaneça, é melhor um governo representativo - até mesmo para não deixar as massas populares se agitarem contra o governo.

A concepção que esses pensadores apresentam acerca do mundo, o foco no indivíduo, o papel do Direito e do Estado, a noção de liberdade, a preocupação com a propriedade, fazem parte do que chamamos liberalismo e suas teorias irão organizar as Constituições contemporâneas, inclusive, a Constituição da República Federativa do Brasil de 1988, que incorpora tanto a república como a federação em sua organização política e que consagra a existência do Poder Legislativo Bicameral, do Executivo e do Judiciário.

O que está na base da teoria liberal são os senhores, a aristocracia, os privilégios feudais. Montesquieu era um nobre e defendia a monarquia, não tinha como proposta uma igualdade entre os cidadãos, da mesma forma que Locke reconhece a servidão e a escravidão 
e os Federalistas encontram vantagem em excluir da política os que não têm propriedade. Foi na afirmação de liberdade dos senhores, em oposição ao despotismo e à monarquia absoluta, que se desenvolveu o liberalismo e sua teoria da combinação dos poderes. Entretanto, as lutas populares já exigiam que, ao menos em tese, o povo, e não mais Deus, fosse o soberano e a fonte do poder político.

\section{Referências bibliográficas}

ALTHUSSER, L. Montesquieu, a Política e a História. Lisboa: Editorial Presença, 1972. Aparelhos ideológicos de Estado. São Paulo: Graal, 2003.

ARISTÓTELES. A Política. In: ARISTÓTELES, Coleção Os Pensadores. São Paulo: Nova Cultural, 1999.

EISENMANN, C. L'Esprit des Lois et la séparation des pouvoirs. In: MALBERG, R. Mélanges. Paris: Sirey, 1933, p. 133-160.

HAMINTON, A; MADISON, J.; e JAY, J. Os Artigos Federalistas, 1787-1788. Rio de Janeiro, Nova Fronteira, 1993.

KRAMNICK, I. Introdução. In HAMINTON, A; MADISON, J.; e JAY, J. Os Artigos Federalistas, 1787-1788. Rio de Janeiro: Nova Fronteira, 1993.

LASLETT, P. Introdução. In: LOCKE, J. Segundo Tratado sobre o Governo Civil. São Paulo: Martins Fontes, 2005.

LOCKE, J. Segundo Tratado sobre o Governo Civil. São Paulo: Martins Fontes, 2005.

MONTESQUIEU, B. Do espírito das leis. In. Coleção Os Pensadores. São Paulo: Nova Cultural Ltda, 1999. 


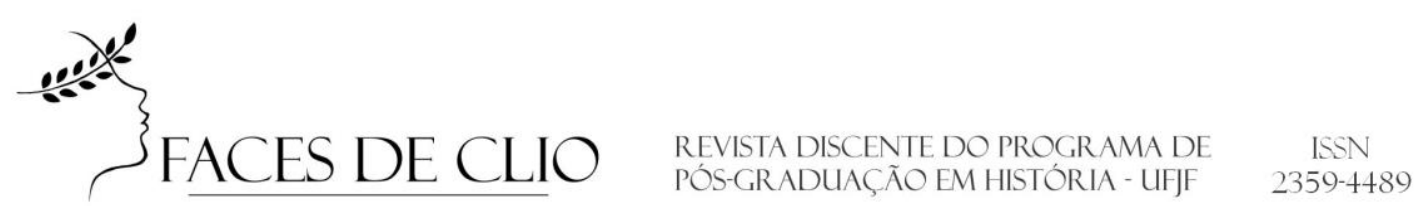

STAROBINSKI, J. Montesquieu. São Paulo: Companhia das Letras, 1990. Montesquieu par lui-même.Paris: Aux Éditions Du Seuil.

VERNIÈRE, P. Dois planos e Duas Leituras. In: QUIRINO, C.; SOUZA, M. (Orgs) $O$ Pensamento Político Clássico. São Paulo: Biblioteca Básica de Ciências Sociais, 1992.

WOOD, E. Democracia contra capitalismo: a renovação do materialismo histórico. São Paulo: Boitempo, 2003.

YOLTON, J. Dicionário de Locke. Rio de Janeiro: Jorge Zahar Editor, 1996. 